to see any suggestive resemblance even in the gross appearance of the spikelets, or in the size, color, shape or texture of their glumes. But were they alike in all these particulars there are certain technical differences which at once separate them generically. E. pilifera is a true Eragrostis, of the section Eueragrostis, and its generic characters are strongly marked. The points separating Eragrostis from Molinia may thus be presented:

Rachilla continuous.

\title{
Eragrostis :
}

Flowering glumes 3-nerved, caducous; palea persistent.

Hilum punctiform.

\section{Molinia:}

Rachilla articulate.

Flowering glumes 5-nerved, falling off with the palea.

Hilum elongated linear.

Molinia is certainly related to Eragrostis and, according to the latest classification, stands next to it following Disanthelium, but the characters separating it are well marked and of such a nature as to exclude it entirely. To open Eragrostis - a genus already overburdened with species and therefore characterized with difficulty-to admit Molinia would be to destroy it.-F. Lamson Scribner, Knoxville, Tenn.

\section{Freaks of roses.}

An article in the September GAzETTE on "Freaks of roses," calls to mind a modification of a rose observed in a cemetery at Cape Girardeau, Mo., about a year ago. The stamens were mostly converted into petals, but the pistils were modified in a curious manner. Some had become leaves similar to those growing on the branches, while in others, half of the carpel was like half of a leaf, the other half remaining carpel-like, being curved inward and having a row of ovules on its margin. Still others had the upper half of the carpel altered to a leaf-like form, the lower half remaining like so much of a true pistil.-W.J. SpILlman, Vincennes, Ind.

\section{CURRENT LITERATURE.}

\section{Scientific Papers of Asa Gray. ${ }^{1}$}

THESE HANDSOME volumes form a worthy memorial of Dr Gray. The wealth of material has made Professor Sargent's task a difficult one, but it is hard to see how he could have done better. To those of us who loved this side of our great botanist these volumes are especially welcome. The nature of the man could not be expressed in the dry details of systematic work; but in his reviews, biographical sketches and essays the bright, genial master found free expression, and his keen but always kind criticism reveals much of the secret of his hold upon American botanists. The present volumes do not include the miscellaneous papers already collected by him in Darwiniana, or his systematic papers, but the remnant gives $\mathrm{u}$ 800 pages of delightful reading, really furnishing " the best account of the

1Sargent, Charles Sprague.-Scientific papers of Asa Gray, selected. Vol. I. Reviews of works on botany and related subjeots (i834-1887), pp, vili. 397, Vol. II. Essays; Biographical sketches (1841-1886), pp. iv. 503. Houghton, Mifflin and Company, Boston
and New York, 1889. 
development of botanical literature during fifty years." His touch was particularly fine in biographical sketches, and that botanist could be counted fortunate whose memory has been embalmed in one of them. It is marvelous that he found time for so much outside work, but he seemed to turn with pleasure from the more exacting labors of a monograph to the writing of miscellaneous papers, which was his way of resting. Profess ur Sargent deserves our thanks for his work, and the volumes should be upon the shelves of every American botanist.

\section{vinor Notices.}

Dr. George VASEy and Joseph N. Rose have published a list of the plants collected by Dr. Edward Palmer in Lower California in 1889, containing the description of thirteen new species. This is a good start in the right direction, and commends itself as one of the proper outcomes of the great collection of plants being accumulated at the National Herbarium. It is but right that the collections of so indefatigable a collector as Dr. Palmer should be carefully studied and made known to botanists. The new species include two Hosackias, a Ribes, an Aplopappus, a Senecio, a Gilia, a Phacelia, a Solanum, an Antirrhinum, a Viguiera, two Encelias and a Krynitzkia.

DR. C. C. PARRY has given additional information concerning Ceanothus, in Proc. Davenport Acad. v. 185-194. It was obtained chiefly by a reexploration of certain regions on the Pacific coast. The care with which this work has been done is to be especially commended, and inspires great confidence in the result. C. intricatus Parry becomes a synonym of C. sorediatus H. \& A.; C. tomentosus Parry is a new species to include what was formerly included under $C$. sorediatus; $C$. Lemmoni and $C$. Orcuttii are both new species; while $C$. dentatus T. \& G. is better defined. This brings our species of Ceanothus to 33, or, including the Mexican species, 36 .

A. P. Morgan's systematic account of N. Am. Gastromycetes has reached the second paper (Jour. Cin. Soc. Nat. Hist., April, 1889). It includes a generic table of Lycoperdaceæ (13 genera), specific descriptions under the first six (Volvatæ), and two colored plates. Two new Geasters are included, and a new genus, Astræus, founded upon the wellknown Geaster hygrometricus Pers.

The second Memoir of the Torrey Botanical Club is a list of marine algæ of the New Jersey coast and adjacent waters of Staten Island by Isaac C. Martindale (issued Aug. 24, 1889). Lists of marine alge are not numerous, and this contribution will undoubtedly stimulate the study of this very interesting and beautiful group. Mr. Martindale has done his work very carefully, giving full credit for his information, and rejecting what was unreliable. The list embraces 91 genera, 183 species and 41 varieties. 


\section{$2 \mathrm{BHL}$ Biodiversity Heritage Library}

1889. "Current Literature." Botanical gazette 14(11), 294-295.

https://doi.org/10.1086/326475.

View This Item Online: $\underline{\text { https://www.biodiversitylibrary.org/item/88789 }}$

DOI: https://doi.org/10.1086/326475

Permalink: https://www.biodiversitylibrary.org/partpdf/221916

\section{Holding Institution}

Missouri Botanical Garden, Peter H. Raven Library

\section{Sponsored by}

Missouri Botanical Garden

\section{Copyright \& Reuse}

Copyright Status: Public domain. The BHL considers that this work is no longer under copyright protection.

This document was created from content at the Biodiversity Heritage Library, the world's largest open access digital library for biodiversity literature and archives. Visit BHL at https://www.biodiversitylibrary.org. 